放 射 線 の 測 定*

\section{1. 放射線測定の原理}

放射性同位元素が各方面に広く応用せられると伴つ て, 放射線の測定技術は最近の数年間飞急激な発達を とげている。

しかしながら，放射線を測定する方法はすべて根本 的には，放射線が物質中を通過するとき飞，その物質 との間任生晾る相互作用を利用して，その効果を適当 に検出するととに基らている。したがつて, 主要な測 定装直の動作機構牥, 比較的少数の基礎的現象に分類 するととができる。

現在われわれの普通取り扱う放射線は，主として $\alpha$ 線， $\beta$ 線， $\gamma$ 線和よび中性子である。 $\alpha$ 線和よび $\beta$ 線 の測定は，それが物質中を通過するときの電離を測定 するととに帰せられる。線の本性は波長の短電磁 波であるが，物質との相互作用として 2 次電子を発生 する。.したがつて，その検出測定は 2 次電子の測定に 㷌せられる。中性子は $\alpha$ 線や $\beta$ 線のような電離作用は きわめて少ならが，原子核との相互作用次より2 次的 に $\alpha$ 線, 陽子線なその荷電粒子を発生するので, それ を利用して検出される。するわち, 放射線の測定は結 局は電離作用の検出測定に帰せられるが, 実際測定に 利用される具体的な効果には次のようなものがある。

\section{(a) 気体の直接の電離作用}

荷電粒子が気体中を通過すると, その飛跡飞沿つて 陰陽イオン対の列がつくられる。適当な電極によつて 気体に電場を加えて和くと, 電離電流として放射線が 検出される。ローリツェン検電器, 電離箱, 比例計数 管,ガイガーミニラー計数管( G-M 計数管) なぞがこ れ飞属する。

\section{(b) 螢光作用}

放射線がある種の固体または液体に当つて発光する 現象在利用しそものである。乙の発光を近年発達し そ光電子増倍管 (photomultiplier tube) 々組合せて 電気的に検出しうるようにしたものがシンチレーショ
木 村 毅 一** 石割隆太郎***

ン・カウンターである.

\section{(c) 写真乳剂の感光作用}

放射線が写真乳剤に対して感光作用を有することは 古くから知られ利用されてきたが，最近，写真乳阂の。 性能が向上して, 荷電粒子 1 箇 1 箇の飛跡を観察する 原子核乾板法，执よび生物組織などの微小部分での放 射性物質の分布を調べるラヂオオートグラフ法が発展 乙た.

\section{(d) 票雾の登生}

過飽和の蒸気を含む気体中にイオンが発生すると， これを核にして水溦ができる：これを利用して荷電粒 子の飛跡を観測するのがウイルソン霧箱であつて原子 核, 宇宙線の研究で広く使わ犺ている。

\section{2. 放射線の基礎的性梊}

上飞述べそ諸効果は，結局は電離作用に帰せられる ものであるから, 各種放射線が気体中で生ずる電離作 用の性質を簡単に述べるととにする。

\section{(a) $\alpha$ 線}

$\alpha$ 線は気体中を质とんぞ方向变えす沉直線的に飛 ぶ. その飛跡沿つて気体分子(または原子) 電離し てイオン対をつくりながらエネルギーを失つて行く. 粒子の電離能力は飛跡 $1 \mathrm{~cm}$ 当りに作られるイオン対 の数, すなわち, イオンの線密度で表わされる.イオ ン線密度は気体の圧力に比例し, 粒子のエネルギーに よつて変化する．第 1 表は $\alpha$ 線が 1 気圧の空気中で生 するるイオンの線密度のエネルギーによる变化を示して らる. 一定のエネルギ一の $\alpha$ 線は物質中で一定の飛程 をもつている.

(b) $\beta$ 線

$\beta$ 線が気体中でイオンをつくる様子は $\alpha$ 線といちじ るしく異なつている。 $\beta$ 線の本性注電子であるから， 物質分子中の電子と衝突してこれを励起, あるいは電 離する己をに進行方向がきわめて变化しやすい，また， 1 回の衝突で失うエネルギーも大幅に変動するので, 第 1 表 1 気圧の空気中での $\alpha$ 線のイオン密度

\begin{tabular}{|c|c|c|c|c|c|c|c|c|c|}
\hline $\begin{array}{c}\text { エネルギ } \\
(\mathrm{MeV})\end{array}$ & $0 \cdot 5$ & 1 & 2 & 3 & 4 & 5 & 6 & 7 & 8 \\
\hline イオン滵度 $\left(\mathrm{cm}^{-1}\right)$ & 45500 & 65900 & 50200 & 39800 & 33200 & 28000 & 24500 & 22000 & 20500 \\
\hline
\end{tabular}

* 原稿受付 昭和 31 年10月 6 日

** 京都大学理学部

**** 京都大学化学研究所
同じエネルギーの $\beta$ 粒子でも，個々の $\beta$ 粒子は，進行 方向和よび到達距離が $\alpha$ 線のよらと揃つていない. 実 際に放射性物質から出る $\beta$ 線はエネルギーが均一でな

昭和 31 年 12 月 
第 2 表 1 気圧の空気中での $\beta$ 線のイオン密度

\begin{tabular}{c|c|c|c|c|c|c|c|c|c|c|c|c|c|c|c|c}
\hline $\begin{array}{c}\text { エネルギ- } \\
(\mathrm{MeV})\end{array}$ & 0.00015 & 0.001 & 0.005 & 0.01 & 0.02 & 0.03 & 0.05 & 0.10 & 0.15 & 0.2 & 0.3 & 0.5 & 1.00 & 2.00 & 4.00 & 10.00 \\
\hline $\begin{array}{c}\text { イオン密度 } \\
\left(\mathrm{cm}^{-1}\right)\end{array}$ & 7700 & 3800 & 1600 & 1050 & 520 & 330 & 250 & 165 & 120 & 95 & 75 & 55 & 44 & 42 & 44 & 46 \\
\hline
\end{tabular}

らから事情はさらて複雑になる。しかし， $\beta$ 線の最大 エネルギーの值に対して, 実際上, $\beta$ 線が阻止される 一定の厚さが存在し，乙れは飛程と呼ばれている。

第 2 表は $\beta$ 線の 1 気圧の空気中に敊けるイオン密度 である。

$\beta$ 線のイオン密度は $\alpha$ 線に比してはるかに小さい. したがつて, エネルギーを失う割合は少なく透過力は 大きい.

このように, イオン密度は粒子の種類, エネルギー によつていちじるしく变化するが，1個のイオン対を つくるために失う平均のエネルギ一(普通 $W$ て表わす) は，粒子の種類扣よびエネルギーに無関係にほぼ一定 である。この值は気体の種類によつてもあまり変化せ ず大体 $30 \mathrm{eV} /$ ionである。第 3 表に各種気体に対する $\alpha$ 線および $\beta$ 線の $W$ 值を示す.

第 3 表 $\alpha$ 線および $\beta$ 線と対する $W$ 值 $(\mathrm{eV} /$ ion)

\begin{tabular}{c|c|c|c|c|c|c|c}
\hline & $\mathrm{A}$ & $\mathrm{He}$ & $\mathrm{H}_{2}$ & $\mathrm{~N}_{2}$ & $\mathrm{Air}$ & $\mathrm{O}_{2}$ & $\mathrm{CH}_{4}$ \\
\hline$\alpha$ 線 & $25 \cdot 9$ & $31 \cdot 7$ & $37 \cdot 0$ & $36 \cdot 0$ & $35 \cdot 2$ & $32 \cdot 2$ & $29 \cdot 0$ \\
\hline$\beta$ 線 & $27 \cdot 0$ & 32.5 & $38 \cdot 0$ & $35 \cdot 8$ & $35 \cdot 0$ & $32 \cdot 2$ & $30 \cdot 2$ \\
\hline
\end{tabular}

これから荷電粒子がつくる全電離量を測れば，その エネルギーを知るととができる。

\section{(c) $\gamma$ 線}

$\gamma$ 線と物質との相互作用は光電効果, コンプトン効 果，和よび電子対創生効果の三つの現象で，らづれも 2 次電子を発生し， $r$ 線はこれらの過程によつてェネ ルギーを失つて行く.

光電効果は $\gamma$ 線のエネルギー全部が原子内の 1 箇の 電子に与えられる過程である。乙の効果は $\gamma$ 線のエネ ルギーの低々所 $(0.5 \mathrm{MeV}$ 程度以下) で主要な役割を 果す過程であつて, その起る確率はだらたい物質の原

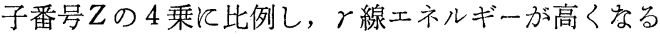
と急速減少する。

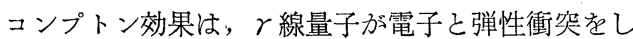
て電子を跳ね飛ばし，みずからも散乱してェネルギー を失う現象である。その確率はZに比例する。跳亦飛 ばされた 2 次電子のエネルギーは，方向によつて異な り, 光電効果のように一定ではない。

電子対創生はと線エネルギーが $1.02 \mathrm{MeV}$ 以上にな ると，物質の原子核の近くで㓌陽の電子対が発生して， と線のエネルギーが全部吸収される現象である、発生
の確率は $Z^{2}$ に比例し，エネルギーの増加とともに急 激に增加する。

\section{(d) 中性子}

中性子は物質中の電子とは法とえご作用しない，物 質との相互作用は，主として原子核との相互作用であ る。最もよく利用されるの注水素原子核との弾性衝突 である。中性子が衝乫すると水素原子核は跳ね飛ばさ れて, らわゆる陽子線として， $\alpha$ 線と同様にして検出 測定される。この陽子のエネルギーを測定すれば中性 子のエネルギーが求められる。

次に, エネルギーの低ら熱中性子の検出には，特に 断面積の大きい $\mathrm{B}^{10}(n, \alpha) \mathrm{Li}^{7}$ おび $\mathrm{Li}^{6}(n, \alpha) \mathrm{H}^{3}$ 反応が利用される。

また，中性子の強度を測定するために，中性子によ る誘導放射能を測る方法もある. $\mathrm{In}^{115}, \mathrm{Ag}^{107}, \mathrm{Ag}^{109}$, $\mathrm{Mn}^{56} ， \mathrm{Au}^{198}$ などは，それぞれ特定のエネルギーの中 性子を共鳴吸収し，しかも断面積が非常に大きいので, この方法に利用される。

\section{3. 放射線測定装置}

\section{（1）放射線による気体の放電}

気体の電離現象を利用する各種の計数装置の動作機 構，执よび区別を理解するをめには，放射線の電離に よる気体放電の性質を総括的に述べるほうが便利であ る.

円筒形の陰極と中心に張られた陽極とからなる計数 管を考える，電極間には適当な気体が満れされてい る、乙の管内反放射線が入射してイオンがつくられる と，正負イオンは笔場によつて陰極扣よび陽極に集め られ，外部の回路にいわゆる電離電流が流れる。この

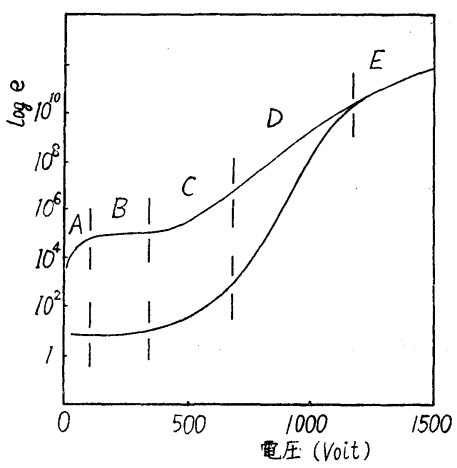

第 1 図 


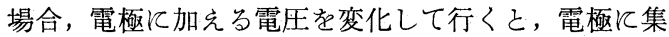
められるイオンの数は第 1 図几示すよらに変化する. 図の二つの曲線は最初, 管内につくられたイオン対の 数が異なる二つの場合を示したもので, 下の曲線は $\beta$ 線のように，最初10箇のイオンが発生した場合，上の 曲線は $\alpha$ 線のように $10^{5}$ 箇のイオンが生じを場合であ る.Aの範囲は電圧が低くてイオン密度の高い場合に は正負イオンが再結合して，つくられたイオン全部は 電極に集まらない。，Bの範囲では，電極ては最初つく られそイオンがそのまま集められる。計数管をこの領 域で働かせる場合飞電離箱と呼んでいる。さらに電圧 を上げてCの領域になると，中心電極に引きつけられ る負イオン(適当な気体では電子)は強的電場で加速さ れ，中心電極洼達する⿱でに気体分子衝突してこれ を電離するようになる。こうしてつくられた電子がま そ加速されて別の分子を電離する，とのように中心電 極の附近で電子の数が鼠算式に增加して行く．とれを 電子なだれと呼んでいる。とのような状態では電極に 集めれらる電荷の量は, 最初につくられれてオン対の 数よりもはるかに多くなる。この現象をガス増幅とい 5. C領域では電压とともにガス増幅率も増加して行 くが，集められる電荷量は初めにつくられたイオン対 の数に比例している. この領域で働かせるのが比例計 数管であつて, この領域を比例計数領域と呼ぶ.ささら 飞電圧を上げて行くと, ガス堌幅率はさらに増加して 行くが，C領域で見られたよらな 1 次イオン数との比 例関係恃失われ，遂には一定の電圧飞対しては，最初 のイオン数に無関係に一定の電荷が集められるように なる。との状態で働かせる計数管がガイガーミニラー 計数管である. この領域をガイガー領域という.

電離電流は多くの場合，1䈯 1 笝の入射粒子飞対応 する電気的脈動として增幅し記録される。加よう飞入 射粒子を 1 箅 1 籄識別して検出する装置を総称して計 数装置と呼んでいる.

\section{(2) G-M 計算管}

使用目的によつて種々の構造のものがあるが，一般 飞金属の円筒の中心に直径 $0.1 \sim 0.3 \mathrm{~mm}$ 程度のピフ ノ線，あるいはタングステン線を張つてある。管の内 部は気密にして，アルゴン，ーリウムなどのガスを数 $\mathrm{cm} \sim 10 \mathrm{~cm} \mathrm{Hg}$ 程度の圧力に満をし, 通常これに数分 の 1 程度のアルコール，アセトンなどの有機蒸気を加 えてある。この添加は計数管の特性を良くするために 是非必要なものである，G-M 計数管は第 1 図の $\mathrm{E}$ 領 域で働かせるのであるが, 単にアルゴン, ヘリウムな ぞを充填してのみでは 1 籄の粒子が入射して放電が始 まると，陽イオンが円筒電極に達するとき飞 2 次電子 を放出する艺め，綝り返し放電が継続して 1 箇の入射 粒子に対して 1 籄の出力脈動を取り出すととがでをな
レ、アルコールなどの有機蒸気を添加すると，との後 続放電を停止させる作用があり，入射粒子を正しく 1 籄 1 筒計数するととがでをるのである。 この作用を自 己消滅(self-quenching)という．添加ガスとして塩素， 臭素なゼハロゲンガスを使うものもある.

G-M 計数管は通常增幅器, スケーラー, 録数器に 接続して計数值を測定するか, あるいは計数率計（レ 一トメーター）飞接続して使われる。

G-M 計数管の特性は次のようにして調べる。，一定 の放射線源を一定の位置飞置いて，管に加える電圧を 変化しながら，一定時間当りの計数をとつて行く。電 压を徐々飞上げてゆくと計数値は第 2 図のようにな る. ある電圧 $V_{0}$ から計数し始好て, ある電圧 $V_{\min }$ か ら $V_{\max }$ の範囲で計数值はほ质一定となる。乙の電圧

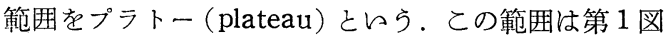
の $\mathrm{E}$ 領域注対応するものである. この曲線を計数特性 曲線という， $V_{\max }$ 以上の電圧では消減作用が不完全 となつて連続放電の起る領域である。

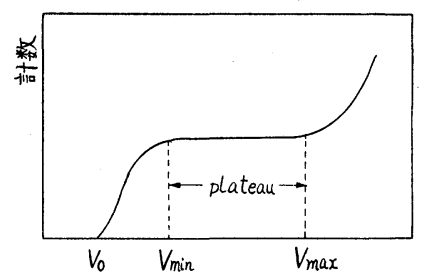

第 2 図 G-M 計数管の計数特性曲線

プラトーは入射粒子 1 箇に対して 1 箇の計数を与え る節囲であつて，特性のより管ではこの簌囲が広く 300 ボルト以上に達する.プラトーは一般に完全に水 平でなく多少傾斜している。この傾をは普通電圧 100 ボルトの変化に対する計数值の変化の\%で表わしス口 ープ (slope) と呼ばれる.スロープは通常数\%以内で ある.プラトーの長さ利よびスロープは計数管の良否 の目安になる、G-M 計数管を使用する際は, 必ず特 性曲線を測定してプラトーの中央よりやや低ら電圧で 使用することが望をしん， G-M 計数管の動作電圧は 管の大きさ，充填気体の種類，圧力によつて異なるが， 多く使われるアルゴン $9 \mathrm{~cm} \mathrm{Hg}$ ，アルコール $1 \mathrm{~cm} \mathrm{Hg}$ 程度のものでは, 始動電圧が 1000 ボル卜程度, プラ トーが 200〜300 ボルトでスロープは $5 \%$ 以内である。 八ロゲンを添加した管では始動電圧はすつと低く, 通 常 1000 ボルト以下で使用されるが，スロープはやや 大きいのが普通である。

計数管は使用していると，だんだん特性が悪くなつ てくる。すなわち，プラトーが短くなり，スロープは 大をくなり，始動電圧が高的ら飞すれてくる。また， 光に対して感じやすくなることもある。乙れは後続放 電防止に添加した有機蒸気の分子が放電のたびに分解 
して消耗するそめであつて, 通常 $10^{8}$ 個ぐらり計数す ると寿命がつをる。使用中ときどき特性曲線を調べる 必要がある。 また $V_{\max }$ 以上の高い電圧を誤つてかけ ると，寿命がロちじるしく短くなるから注意せねばな らない。、ハロゲン計数管では，フルコール分子のよう 飞分解しるらので寿命はもつと長ら. $10^{10}$ 個程度の寿 命があるといわれている.

計数管は 1 箇の粒子が入射して放電が始まると, そ の放電が完了して次の粒子を計数しうる状態をで回復 するのに一定の時間を必要とする．乙の回復時間内に 第 2 の粒子が入射しても計数管は動作しなら. 測ろう とする放射線の強度が強らときとは, 短時間間隔で 多くの粒子が入射するから，乙の回復時間内に入射し そ粒子は数え落されることになる，回復時間は管の大 きさ, 気体の種類, 圧力によつて異なるが, だらたい 1〜 $5 \times 10^{-4} \sec$ の程度である. 早ら計数をするとをに は, 数え落しが問題となる。

G-M 計数管は 正しい電圧で働かせを場合, 有效体 積内凡入射する $\beta$ 線は実際上 $100 \%$ の効率で計数する。 $\gamma$ 線汢気体との相互作用の確率注非常に小さらので, 主として, 管壁加ら放出される 2 次電子によつて計数 されるが，その計数効率は一般に $1 〜 2 \%$ 程度であ る. 八ロゲン計数管は $\beta$ 線に対して約 $70 \%$ 程度の効率 であるといわれている。

まを，計数管は放射線源を取り去つても，周囲执よ ど自身の材料中に含まれる微量の放射性物質や宇宙線 のために少しの計数が残る。これを自然計数 (natural background)という. 普通使用する計数管では毎分 20 〜30前後である. 测られた計数值から必市自然計数を 差引かねね゙ならない。

\section{(3) 比例計数管}

第 1 図の比例計数領域で動作させる計数管である. ガス增幅を利用するが，出力脈動は入射粒子のつくる 1 次イオン数飞比例するので， $\alpha$ 線， $\beta$ 線， $\gamma$ 線の区 別をして測定がでをる. 使用する気体は通常アルゴン, ヘリウム，ネオンなど飞安定気体として数\%のメタン， アルコール，ブタン， $\mathrm{CO}_{2}$ なぞを加えて使用する。 ま そ, 純メタンガスも良好な特性を示す。一般飞純度の よい気体を使う必要がある。気体の圧力は G-M 計数 管の場合のよう亿低的必要はなく，1気圧前後よりさ らに数気压に及ぶこともある。電圧をあまり高くする そ, 比例計数領城からはずれてくるので, 普通ガス增 幅率 10 1 000 の程度で使用される。電圧が変化する とガス增幅率が急激に变るから, 高電圧は G-M 計数 管よりも安定度の良電源が必要である。

比例計数管の利点の一つは, ウわゆるフローカウン ターとして使用できるととである。 G-M 計数管の場 合には $\beta$ 線は雲母空を通して外部より入れるので，
$\mathrm{C}^{14}, \mathrm{~S}^{35}, \mathrm{Ca}^{45}$ などのエネルギーの低ら $\beta$ 線では, 雲 母空や空気の吸収のため計数の能率がロちじるしく悪 くなる．比例計数管は 1 気圧で働かせるととができる ので，適当な開閉装置で管内に放射性試料を入れて， 少量の気体を 1 気圧で管内を流しながら測定する。 $\beta$ 線江雲母空や空気層を通さ市直接住計数管の有効体積 に入射するので，計数効率が非常によくなる．との型 の計数管をフローカウンター，まをは windowless counter という.

比例計数管はまた, $\mathrm{BF}_{3}$ やあるいはメタンを充媜し て中性子用計数管として広く利用されている。

\section{(4) シンチレーション・カウンター}

シンチレーション・カウンターの主要部分は, 外部 から入射する放射線を受けて発光する螢光体と, 螢光 体の発する閃光を受けてと礼を電気的な脈動として取 り出す感度の高々一種の光電管である光電子増倍管か ら成る. 光電子增倍管は次飞比例增幅回路, 脈動選択 回路, 計数回路飞接続される.

\section{(a) 光電子增倍管}

光電子増倍管の構造を模型的飞第 3 図に示す. これ は光に対する感度の高い $\mathrm{Cs}_{3} \mathrm{Sb}$ などの光電陰極と, それから出る光電子が衝突すると数䇫の 2 次電子を放 出する 2 次電子放出電極 (dynode という) 約10段症 ぞ含んぞ光電管である，放射線が螢光体に入射する と閃光が生じ, 乙れが光電子増倍管の光電陰極に当つ て光電子が発生する。乙れが 1 段のダイノード酒突 すると一般飞 $3 \sim 5$ 個の 2 次電子を放出しらるから， 約10段で最終段飞達する電子の增倍率は $10^{6}$ 程度であ る. 各ダイノード間には $100 \sim 150$ ボルト程度の電圧 をかけるが, との電圧が変化すると, 堌倍率が変化す るから，よく安定した電源を使う必要がある。第 4 表 飞和もな光電子增倍管の特性を示す.

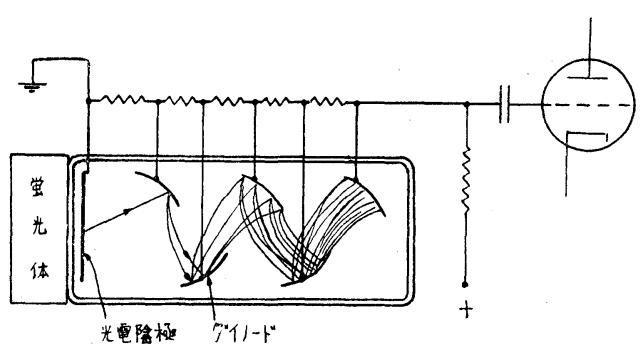

第 3 図 光電子増倍管

光電子増倍管には光が入射しないときにも，いわゆ る暗電流飞よる雑音が伴う. 暗電流は, 光電面ある々 はダイノードからの熱電子放射, fiield emission, 絶 緑不良などに原因する。 また, 光電子增倍管は明るい 所では決して電圧を加えてはならない。

\section{(b) 螢光体}

現在使われている螢光体には, 無機結晶, 有機結晶, 
第 4 表 光電子増倍管の 特 性

\begin{tabular}{|c|c|c|c|c|c|c|c|c|c|}
\hline 管 & & $\begin{array}{l}\mathrm{RCA} \\
5819\end{array}$ & $\begin{array}{l}\mathrm{RCA} \\
6342\end{array}$ & $\underset{6292}{\text { DuMont }}$ & $\underset{6363}{\text { DuMont }}$ & $\underset{6364}{\text { DuMont }}$ & $\begin{array}{l}\text { FMI } \\
5311\end{array}$ & $\begin{array}{l}\text { EMI } \\
6260\end{array}$ & $\begin{array}{l}\text { EMI } \\
6262\end{array}$ \\
\hline 光電㓌極面栍 & $\left(\mathrm{cm}^{2}\right)$ & 11 & 11 & 13 & $30 \cdot 6$ & 86 & 5 & 15 & 15 \\
\hline 感光曲線の山 & $(\AA)$ & 5000 & 4000 & 4900 & 4000 & 4000 & 4100 & 4100 & 4100 \\
\hline 陰 極 戚 度 & $(\mu \mathbf{A} / \mathbf{l m})$ & $20 \sim 40$ & $40 \sim 60$ & $40 \sim 60$ & $40 \sim 60$ & $40 \sim 60$ & $20 \sim 40$ & $20 \sim 40$ & $20 \sim 40$ \\
\hline 全印加電匠 & (V) & 1250 & 1500 & 1800 & 1800 & 1800 & 2000 & 2000 & 2000 \\
\hline 数 & & 10 & 10 & 10 & 10 & 10 & 11 & 11 & 14 \\
\hline 各段当りの電圧 & (V) & 90 & 125 & 145 & 145 & 145 & 160 & 160 & 160 \\
\hline 電流增幅率 & & $6 \times 10^{6}$ & $6 \times 10^{6}$ & $2 \times 10^{6}$ & $2 \times 10^{6}$ & $2 \times 10^{6}$ & $10^{7}$ & $10^{7}$ & $5 \times 10^{3}$ \\
\hline 最大電 流 & $(\mu \mathbf{A})$ & 0.75 & $2 \cdot 0$ & $3 \cdot 2$ & $3 \cdot 2$ & $3 \cdot 2$ & $1 \cdot 0$ & $1 \cdot 0$ & $1 \cdot 0$ \\
\hline 陽極暗電流 & $(\mu \mathrm{A})$ & 0.05 & 0.02 & 0.05 & 0.05 & 0.05 & 0.1 & 0.1 & $5 \cdot 0$ \\
\hline 長 & $(\mathrm{cm})$ & $14 \cdot 7$ & $14 \cdot 7$ & $14 \cdot 1$ & $13 \cdot 4$ & $16 \cdot 9$ & 21 & $11 \cdot 7$ & $12 \cdot 5$ \\
\hline 径 & $(\mathrm{cm})$ & $5 \cdot 6$ & $5 \cdot 6$ & $5 \cdot 0$ & $7 \cdot 5$ & $13 \cdot 1$ & 5 & 5 & 5 \\
\hline
\end{tabular}

第 5 表 シンチレーション・カウンターに使われる螢光体

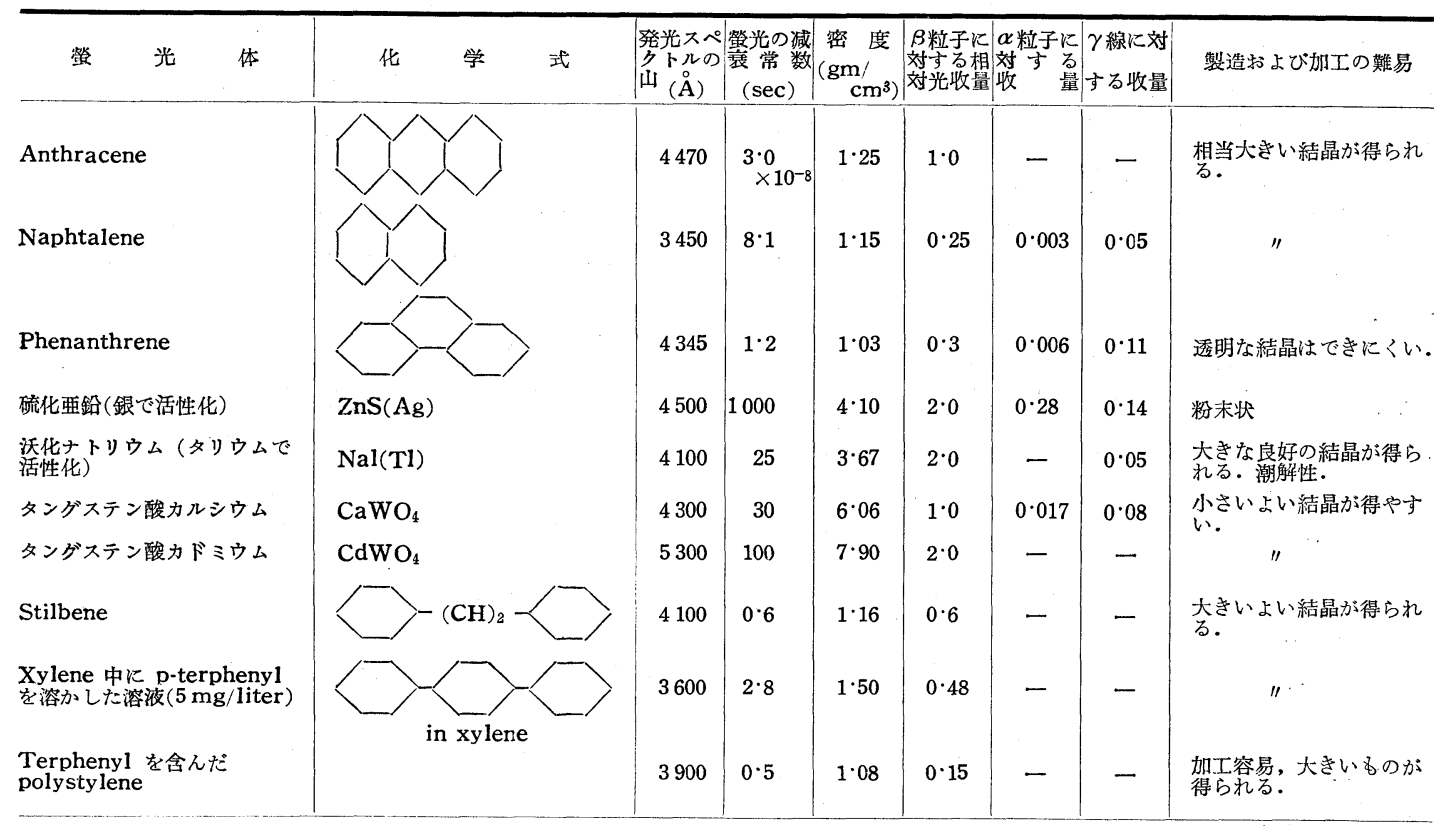

液体叔よびプラスチック䝁光体がある。一般的に望ま しい特性としては, 光の収量が大きく, 螢光の減衰時 間常数が小さく，発光の波長が光電子增倍管の感度特 性と適合しているとと，透明なととなどである。また， 大きいすのがつくりやすいか，加工が容易であるかど らかも使用上問題となる。また，螢光体の中で吸収さ れる入射粒子のエネルギーと光收量との比例性のよい ことも望ましい特性の一つである。

第 5 表によく使用される螢光体の性質を示す.

$\mathrm{NaI}(\mathrm{Tl})$ は光収量も大をく透明で大型のものが得ら れるとと，原子番号の大をい沃素を含むためと線に対 する感度がよらので，r線測定用に最も広く使用され る標準的結晶である。潮解性が強らので密封したま ま使用する必要がある。

有機結晶としては,アントラセン和よびスチルベン
が代表的なものである．特にスチルベンは螢光の減衰 常数が $10^{-8} \mathrm{sec}$ 以下で早的計数に適している. 主とし $\tau, \beta$ 線の測定沉用的られる゙，きわめて脆く加工が むすかしい．また，有機結晶は水素を含んでいるので 速的中性子用としても使われる。

プラスチック螢光体は機峨加工できるとと，熱可塑 性を利用して適当な形にモールドでをる利点を持つて らる. 光収量はやや少ないが, 䝁光の減衰時間常数は 小さら，将来，有機結晶よりも多く使われる勢いにあ る。

第 4 図は， $\beta$ 線が螢光体飞吸収されて失らェネルギ 一と光收量の比例性を示している.

シンチレーション・カウンターの特徽柱, 分解時間 が 10-6 $10^{-8} \mathrm{sec}$ であつて G-M 計数管に比してはる かに早的計数和よび同時計数に適しているとと，適当 


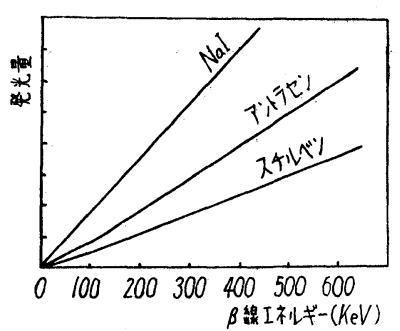

第 4 図 $\beta$ 線江対する発光量と吸収 エネルギーの関係

な螢光体を使うとて線に対する計数効率を数10\%まで 高めることができるととなどである.

\section{4. $\beta$ 線の測定}

現在 $\beta$ 線の測定に最も広く使われているのは, 薄い 雲母空を持つ終端密型の G-M 計数管である。 $\beta$ 線の 測定といつても，をとえば，半減期の測定，吸収係数 の測定から試料中に含をれる放射性物質の種類を分析 する問題, あるいは放射線の性質を調べる問題なぞ多 種多様である。ここでは，放射性物質の種類が既知の 場合, 試料の放射能の強さから試料中に含まれる放射 性物質の量学決定, ある々は比較する問題について述 ベる.

\section{(1) 計数值と放射能強度との関係}

普通 $\beta$ 線の測定では, 計数管と試料との位置を一定 にして測定の条件の再現性を得るために計数箱が用い られる。 G-M 計数管は箱の上部《固定され，試料は プラスチックなどでつくられそ板の中央に固定して， 計数管の下に取り付けそ棚の適当な段に插入し，計数 管からの距離和よび位置を固定して測定する。

試料中凡含まれる放射性物質の量は, 放射能強度 $D$ (disintegrations/min., dpm とも書く) で表わされ る. 一方, 乙の試料加出る $\beta$ 線㳇幾何学的配置, 吸 収, 散乱の影響のため, その一部分が計数管に入射し て計数される. 計数值 $n$ (counts/min., $\mathrm{cpm}$ と書く) 之放射能強度 $D$ との間には一般に次の関係が成立す る。

$$
D=\frac{n}{G \cdot f_{C} \cdot f_{W} \cdot f_{A} \cdot f_{H} \cdot f_{B} \cdot f_{S}}
$$

ここで分母の $G, \cdots, f_{S}$ はそれぞれ次の現象に関 する補正項である。

$G$ : 計数管と試料の幾何学的配置に対する補正項

$f_{C}$ : 自然計数扣よび計数管の分解時間にもとすく数 え落しの補正項

$f_{W}$ : 試料と計数管の間の空気および計数管の空によ る吸収の補正項

$f_{A}$ : 試料と計数管との間の空気による散乱の補正項

$f_{H}$ : 試料皿以外の周囲の物体からの散乱に対する補 正項
$f_{B}$ : 後方散乱 (backscattering), すなわち, 試料か ら出る $\beta$ 線が試料皿から散乱されて計数管に入 る影響の補正項

$f_{S}$ : 自己吸収 (self-absorption) および自己散乱 (self-scattering)，すなわち，試料自身による 散乱扣よび吸収の影響の補正項

計数値 $n$ を測定して, これから試料の強度の絶対值 を求めるためには, とれらの補正項の值を知る必要が ある。乙かし，放射性物質をトレーサーとして使用す る多くの実験では，一連の試料の相対的強度を測れば 充分な場合が多ら。しそがつて，乙れらの補正項全部 を知る必要はないが，測定を能率よく行うためには， レくつかの項の影響は考虑しなければならない。

幾何学的配置の項 $G$ 試料から計数管の悹を望む立 体角によつて定まる。一般に試料はある広がりをもつ そ円形隹調整されるから，試料面上の各点から計数管 の空を見る立体角は各点により異なり, 試料全体とし ての有効立体角の計算はかなり複雑となる。しかし， 各試料の比较測定でけを行えばより場合には, 試料の 大きさ和よど位置を一定にして条件を固定すれば， $G$ は考慮の外飞扣くことがでさる．測るべを試料の強度 が非常治強的のと弱的ものある場合飞, 強試料 を計数管から遠去けて測定しなケればならぬ場合もあ るが，とのような時には，あらかじめ一定の標準試料 を使つて計数管加らの距離を順次变えて計数値をとつ て, 幾何学的配置による計数能率の变化を較正して和 けばよロ，有効立体角の大ささを知りをい場合には文 献の図叔よび表を利用すればよら。

空気と雲母空による吸収の項 $f_{W}$ は一般涹数 $\mathrm{mg} /$ $\mathrm{cm}^{2}$ の程度であつて， $f_{W}$ の值を知る必要のあるとき 飞は, 各実験条件飞和いて実験的飞吸収曲線を求め, 乙れを厚さの薄い质ら反外插して求める方法がとられ ている、 $\mathrm{C}^{14}$ などの低エネルギーの $\beta$ 線では，乙の吸 収のために計数効率がロちじるしく低くなる。

$f_{A}$ の項侙料を計数管からあまり遠去けない限り 無視してさしつかえない。

$f_{H}$ あ通常ほとえぼ無視できる. 市販の計数箱では 試料を何段目の棚飞和くかで多少異なるが，1４\%の 程度である。

しかし， $f_{W}, f_{A}, f_{H}$ は比較測定を行う場合には 各試料に対して同一条件であるから考虑する必要はな ら．ただし，測定の途中で計数管が破損して取換えた りする場合には条件が变化する。 とのような不虑の事 故借六て, あらかじめ較正用の標準試料を準備して その計数を詳しくとつて和けば, 計数管を取換えても $f_{W}$ の変化を較正しうるから便利である。

放射性物質をトレーサーとして使用する普通の実験 では,きわめて薄い膜の上に,きわめて薄く試料を付け 
て, 後方散乱や自己散乱の影響を無視しうるような条 件を実現することはほとんぞ望みえない。したがつて， 普通のトレーサーの実験で比較測定を行うときに, 最 も問題となるのは $f_{B}$ および $f_{S}$ の補正である.

\section{(2) 後方散乱の性質}

試料から出る $\beta$ 線は試料皿で後方散乱して計数管に 入るから，乙のために計数が増加する。乙の増加は試 料血の材質, 厚さ, $\beta$ 線のエネルギーに関係する. 後 方散乱の性質を調べるために，ます放射性物質をきわ めて薄いコロヂオン膜につけ, 後方散乱の影響のない 状態で計数 $N_{0}$ 起測定する. 次反使用する試料皿と同 じ厚さの同じ物質をコロヂオン膜の背面に密接させる と, 後方散乱のために計数は增加して $N_{b}$ となる. $f_{B}$ の值は $f_{B}=N_{b} / N_{o}$ で与えられる.

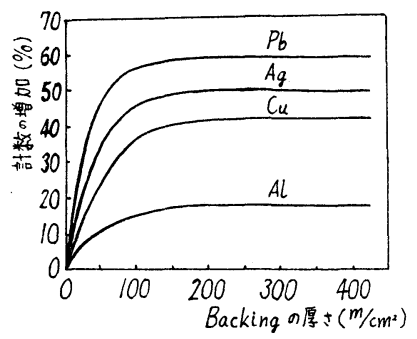

第 5 図 $\mathrm{P}^{32}$ の $\beta$ 線の後方散乱

第 5 図は $\mathrm{P}^{32}$ の 線を使つて, 種々の物質の backing の厚さを増して行くときの, 後方散乱による計数の増 加の有様を示している. 図からかかるように, backing の厚さがある値に達すると計数の増加は飽和值に達す る. この飽和て達した backing の厚さ $M_{S}$ は $\mathrm{mg} / \mathrm{cm}^{2}$ で表わすと backingの物質には無関係で， $\beta$ 線の最大 エネルギー $E_{\max }$ のみによつて定まる. Yaffe によれ ば $M_{S}$ と $E_{\max }$ の関係は近似的に

$$
M_{S}{ }^{3}=116 E_{\max ^{2 / 3}}, E_{\max }<3 \mathrm{MeV}
$$

で与えられる。ただし $M_{S}$ は $\mathrm{mg} / \mathrm{cm}^{2}, E_{\max }$ は $\mathrm{MeV}$ である。

また，飽和後方散乱に和ける計数の增加は backing の物質の原子番号 $Z$ と共に増加し，また $\beta$ 線のエネル ギーにも関係する。すなわち， $E_{\max }$ が $0.6 \mathrm{MeV}$ 以上 の $\beta$ 線に対しては計数の増加は $\mathrm{Al}$ で $20 \sim 30 \%, \mathrm{Cu}$ で50\%程度， $\mathrm{Pb}$ で 70 80\% 亿達する． $E_{\max }$ が 0.6 $\mathrm{MeV}$ 以下では計数の増加はエネルギーと共に増大す る。

同じ放射性物質を含む一連の試料の強度の比較測定 を行いてい場合には，各試料に対して $f_{B}$ を一定に するととが必要である。そのためには，試料皿はすべ て同一材質のものを用々, 厚さは充分に嬮くして飽和 後方散乱を与えるようにするとよい，第 5 図に示すよ らな曲線の急上昇する部分の厚さにしておくと, 各且 のわずかな厚さの差がかなりの誤差の原因になる恐れ
がある，必要な厚さは $\beta$ 線の最大エネルギーによつて 異なるから，Yaffe の式によつて調べて扣く必要があ る。

\section{（3）自己吸収と自己散乱}

一定の割合に放射性物質を含み，厚さの種々飞異な る試料を作り,一定の位置に置々て测定し計数值と厚 さとの関係をみると第 6 図の $N$ 曲線のようになる。試 料の真の強度は厚さに比例する筈であるから, 直線 $N_{t}$ となる。試料の下層から出る $\beta$ 線は上層部で吸収 散乱されるため, 測定值 $N$ は厚され比例せず, 試料 中での $\beta$ 線の飛程より少し小さい厚さの附近で飽和に 達する. 飽和計数值 $N_{\infty}$ を infinite thickness activity という。Nの曲線が純粋に吸収のみによるものであれ ば， $N_{t}$ は $N$ 曲線の立上りに和ける切線となる筈で ある。ところが実際は厚さの薄い所（試料中での $\beta$ 線 飛程の 5 10\%程度) では図に示すように $N$ 曲線が $N_{t}$ の上に出る。乙れは $N$ 曲線の形は散乱の影響も受 けているととを表わすもので，薄い所では吸収による 減少が比較的少なく, 試料中での自己散乱によつて余 分の $\beta$ 線が計数管に入るために計数が増加するものと 考えられる。

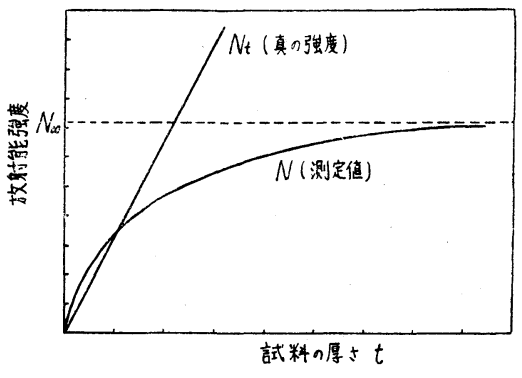

第 6 図

次に，自己吸収の一般的な性質を考えてみる。試料 の中での $\beta$ 線の吸収が通常の吸収の式

$$
I=I_{0} e^{-\mu t}
$$

で表わされるものとする. 試料の厚さを $t$ とし, 試料 の単位厚さ当りの真の強度を $n_{0}$ とすると, 表面から 深さ $x$ の所にある厚さ $d x$ の層から試料表面に出てく る $\beta$ 線の強度は

$$
n(x) d x=n_{0} e^{-\mu \cdot x} d x
$$

したがつて, 試料全体から表面に出てくる強度 $N$ は

$$
N=\int_{0}^{t} n_{0} e^{-\mu x} d x=\frac{n_{0}}{\mu}\left(1-e^{-\mu t}\right)
$$

となる。乙れが第 6 図の $N$ 曲線に相当する。 infinite thickness activity $N_{\infty}$ は( 5 )より

$$
N_{\infty}=\frac{n_{0}}{\mu}
$$

一方, 真の強度 $N_{t}$ は

$$
N_{t}=n_{0} t
$$

$N$ と $N_{t}$ との比をとると 


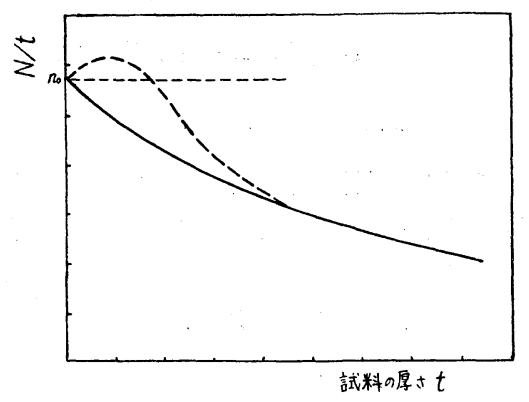

第 7 図

$$
\frac{N}{N_{t}}=\frac{1-e^{-\mu t}}{\mu t}
$$

吸収係数 $\mu$ は常数であるから (8) 式の形は, 試料 の単位厚さ当りの計数值 $N / t$ と同じ形をとる. 第 7 図にこの形を示す. (8)式の形は図の実線で表わさ れるが，実際に $N$ を測定して $N / t$ を求めてみると， 図の点線のように試料中での $\beta$ 線飛程の $5 \sim 10 \%$ 附 近で(8)式の形からすれて, $N / t$ の $t \rightarrow 0$ の極限值 $n_{0}$ よりも大きい值となる。乙れは試料中の散乱の影響で 第 6 図で $N$ 曲線が $N_{t}$ の上に出る部分に対応している.

厚さ $t$ の試料に対する補正項 $f_{S}$ は

$$
f_{S}=\frac{N}{N_{t}}=\frac{(N / t)_{t=t}}{(N / t)_{t \rightarrow 0}}
$$

で与えられる。 $N$ が正確に( 5 )式で表されるときには

$$
f_{S}=\frac{N}{N_{t}}=\frac{1-e^{-\mu t}}{\mu t}
$$

となる、第 7 図の点線の部分では $N$ ( 5 )式からずれ てくるために式で簡単に表わせない.

実際問題として，同一の放射性物質を含む一連の試 料の強度を比較するとき， $f_{S}$ の補正をいかにすべき かは $\beta$ 線のエネルギーと試料の厚さによる。

試料の厚さが $\beta$ 線の飛程に比して充分厚くとれる場 合には, 計数值は infinite thickness activity とな るから, 試料の厚さに関係なく放射性物質の含有量 (specific activity, $n_{0}$ ) 飞比例する.したがつて, $f_{S}$ は考える必要はない，試料の分量が充分にとれない場 合には，既知の放射性物質を含み，厚さの異なる試料 をつくつて，第7図の曲線の形をあらかじめ実測で求 めて補正することが望ましい.

一般に $\mathrm{P}^{32}$ のようにエネルギーの大き々 $\beta$ 線では厚. い試料をつくるととが困難で, 第 7 図の点線で表わし そ状態沉なることが多々， $\mathrm{C}^{14}, \mathrm{Ca}^{45}$ などのエネルギ 一の低らものでは, 試料の厚さが第 7 図の点線部より も厚々方に相当するととが多い. この場合には実験的 に $\mu$ 疗めて (8)式によつて $f_{S}$ 在求めるととがでを る.

\section{5. $\gamma$ 線 の 測 定}

すでに述べたように，シンチレーション・カウンタ
一は, $\gamma$ 線に対する䛨数効率が高く，また，脈動の大 きさからと線のエネルギーの分析もできるので, G-M

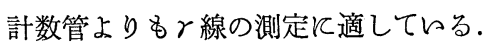

一般に, $r$ 線の相互作用には, 光電効果, コンプト ン効果, および電子対創生の三つの過程がある. 光電 効果に扣いてはと線のエネルギーの大部分は 2 次電子 に与えられ，そのエネルギーは完全に螢光体の中で吸 収される. 残りの小量のエネルギーは, 残された原子 からX線として放射される。乙のエネルギーは螢光体 内で吸収されるとともあり，ときには外部に逃れ去る こともある. 多くの場合, 光電効果に扣々てはと線工 ネルギーは全部吸収されて，そのエネルギーに相当す る所に脈動分布のピークが得られる.

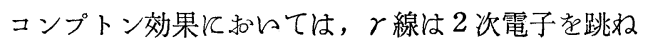
飛ばして，みずからも散乱してエネルギーを失ら。

しそがつて，1回の散乱で全エネルギーが吸収されな ら. 2 次電子のエネルギーは角度によつて变化し, そ の分布は広がりを持ち, 一般にエネルギーの大きい端 に山が出る、コンプトン散乱では一度散乱すると， 2 次電子のエネルギーは螢光体内で吸収されるが, 散乱 したて線はそのまま螢光体外に逃げ去るとともあるし， さらに続いて散乱, あるいは光電効果を起して, その エネルギーの一部あるいは全部が螢光体内で吸収され るとともある。したがつて, 多数の脈動の分布を調べ ると, コンプトン効果による脈動は幅の広い分布とな る. 吸収エネルギーと発光量が比例する場合には, 全 エネルギーが何回かの過程で螢光体内に吸収されたと きの脈動は, 1 回の光電効果で全エネルギーが吸収さ れをときのピークと一致する。

$r$ 線エネルギーが $1.02 \mathrm{MeV}$ 以上になると電子対創 生が起る。この場合, $\gamma$ 線エネルギーから $1.02 \mathrm{MeV}$ を引いそ差が, 生じた陰陽電子のエネルギーの和であ つて, これは完全に螢光体に吸収される。㓌陽電子の エネルギーが吸収された後, 陽電子は螢光体中の除電 子と結合して消隇し, そのとき $0.511 \mathrm{MeV}$ の二つの $r$ 線が互に逆方向に放出される. これら二つの 両方とも螢光体から逃げ去るとともあり, 一方が吸收 されるとともあり，また，両方とも吸収されることも ある.したがつて, 電子対創生による脈動の分布には 三つのピークがあつて, 最も大きいものは全土ネルギ 一が吸収されそ場合である。

一般にコンプトン効果は, 明瞭なピークをつくらな らが，螢光体の原子番号Zが大きくなると，コンプト ン効果に比して光電効果执よび電子対創生の確率が増

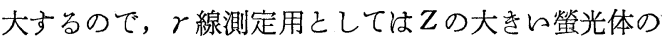
疼うが有利である。 ものは $\mathrm{NaI}(\mathrm{Tl})$ である. $\mathrm{NaI}$ は潮解性があるので, アルミニニームのケースに納めて気密にしたまま使用 
する. 結晶のまわりに $\mathrm{MgO}$ の反射層を置を, 光が外 部に逃げ出すのを防ぐ. 光電子增倍管に接続する部分 はガラス, あるレはルサイトの空にする. 少量のシリ コングリースを塗つて全反射を防ぎ光電子増倍管に接 続する. 結晶は円筒形のものが効率がよく, 直径 $1 \frac{1}{2} 2$ in, 高さ 1 in 程度のものが多く使われている.

第 8 図およど第 9 図は $\mathrm{NaI}(\mathrm{Tl})$ でとつたと線の脈 動分布の例である. 第 8 図は $\mathrm{Cs}^{137}$ の 0.661 Mev のr 線の場合である. 実線は 1.5 in $\phi \times 1$ in, 点線は 3 in $\phi$ $\times 3$ in の場合である. 光電効果のピークとコンンプトン 効果の幅広ら山が現われている. 結晶が大きいほど最 大エネルギーに相当するピークは顕著になる。第 9 図 は $\mathrm{Na}^{24}$ のと線で, $1 \cdot 38 \mathrm{MeV}$ 和よび $2 \cdot 76 \mathrm{MeV}$ の二つ

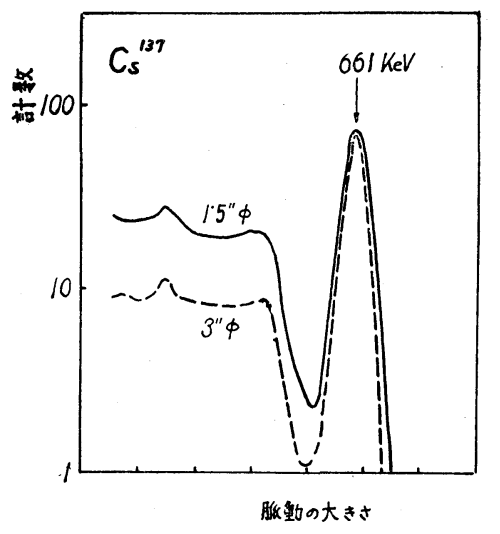

第 8 図 $\mathrm{Cs}^{132}$ の $r$ 線の脈動分布

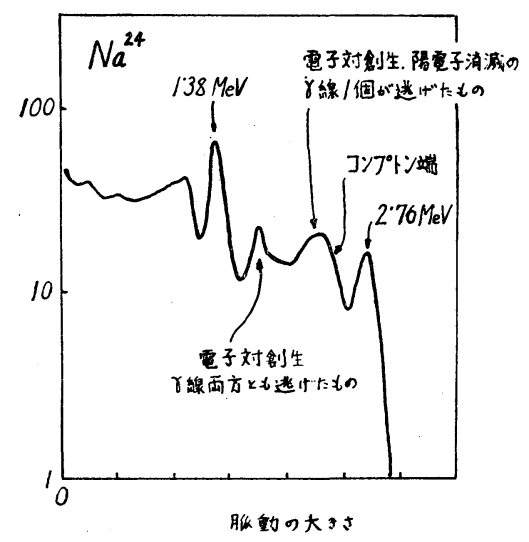

第 9 図 $\mathrm{Na}^{24}$ のr線の脈動分布
である。結晶は $1 \frac{1}{2}$ in $\phi \times 1$ in である。エネルギーが 高くなると, 全エネルギ一の吸収された最大ピークは 顕著でなくなつてくる.

一定のエネルギーのノ線が入射しても, 光収量の動 摇, 光電子の収量和よび 2 次電子増倍率の動摇, 光電 子増倍管の暗電流, 増幅回路の雑音などのために出力 脈動の分布はある幅広がつてしまう。エネルギーの 分解能はピークの半值幅の\%で表わされる. 普通条件 るのよらときで $6 〜 7 \%$ 程度である.

注: 一

1) S.A. Korff, Electron and Nuclear Counters, Van Nostrand (1946)

S.G. Curran and J.D. Craggs, Counting Tubes, Butterworths (1949)

B. Rossi and H.H. Staub, Ionization Chambers and Counters, McGraw-Hill (1949)

D.H. Wilkinson, Ionization Chambers and Counters, Camb. Univ. Press (1950)

2) S.G. Curran, Luminescence and Scintillation Counters, Butterworths (1953)

J.B. Birks, Scintillation Counters, Pergamon Press (1953)

3) H. Yagoda, Radioactive Measurements with Nuclear Emulsions, Wiley (1949)

4) H.H. Staub, Detection Method, Experimental Nuclear Physics, Vol. 1, Wiley (1953)

5) L.I. Schiff, Phys. Rev. 50, 88 (1936)

A.E. Ruark and F.E. Brammer, Phys. Rev. 52, 322 (1937)

L. Alaoglu and N.M. Smith, Phys. Rev. 53, 832 (1938) P.E. Damon and P.N. Winters, Nucleonics, Vol. 12, No. 12, 36 (1954)

6) H.O. Anger et al, Conference on Absolute $\beta$ Counting, Preliminary Report No. 8, NRC (1950)

B.P. Burtt, Nucleonics, Vol. 5, No. 2, 28 (1949)

G.I. Gleason et al, Nucleonics, Vol. 8, No. 5, 12 (1951)

C.L. Comar et al., Nucleonics, Vol. 8, No. 3, 19 (1951)

7) G.B. Cook et al, Nucleonics Vol. 8, No. 1, 24 (1951) A.H. Jaffey, Rev, Sci, Inst, 25, 349 (1954)

参考書

1) G.B. Cook and J.F. Duncan, Modern Radiochemical Practice, Oxford Clarendon Press (1952)

2) G.J. Hine and G.L. Brownell, Radiation Dosimetry, Academic Press (1956)

3) W.E. Siri, Isotopic Tracers and Nuclear Radiations, McGraw-Hill (1949)

4) G.K. Schweitzer and I.B. Whitney, Radioactive Tracer Techniques, D. Van Nostrand (1949)

5) G. Friedlander and J.W. Kennedy, Introduction to Radiochemistry, Wiley (1949)

6) 化学の領域, 增刊17, アイソトープ実跧技術, 第 1 集, 南汇堂

7) 実験化学講坐, Vol. 12, 放射化学, 丸善

8）原子力工業講座, Vol. 2, 放射線測定装置, 共立出版 